ENTREPRENEURSHIP AND SUSTAINABILITY ISSUES

ISSN 2345-0282 (online) http://jssidoi.org/jesi/

2020 Volume 8 Number 2 (December)

http://doi.org/10.9770/jesi.2020.8.2(2)

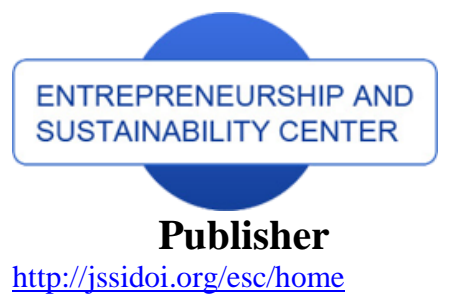

http://jssidoi.org/esc/home

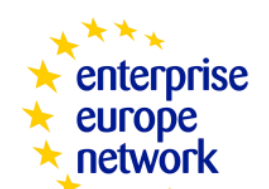

Business Support on Your Doorstep

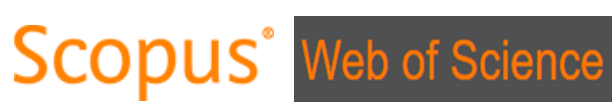

1) Clarivate

Analytics

\title{
CONTROLLED FOREIGN COMPANIES: INFLUENCE ON THE SOVEREIGNTY OF THE NATIONAL TAX BASE
}

\author{
Liudmila I. Khoruzhy ${ }^{1 *}$, Malvina R. Karabasheva ${ }^{2}$, Hafis Ahmed oglu Hajiyev ${ }^{3}$, \\ Natalia N. Zhadobina ${ }^{4}$, Natalia A. Alekhina ${ }^{5}$, Rustem A. Shichiyakh ${ }^{6}$ \\ ${ }^{1 *}$ Russian State Agrarian University - Moscow Timiryazev Agricultural Academy, Timiryazevskaya street, 49, 127550, \\ Moscow, Russian Federation \\ ${ }^{2}$ Financial University under the Government of the Russian Federation, Moscow, Russian Federation, Leningradsky \\ Prospekt, 49, 125993, Moscow, Russian Federation \\ ${ }^{3}$ Azerbaijan State University of Economics (UNEC), Istiqlaliyyat street 6, AZ1001, Baku, Republic of Azerbaijan \\ ${ }^{4}$ Surgut State University, Lenin Ave., 1, 628403, Surgut, KhMAO - Ugra, Russian Federation \\ ${ }^{5}$ Sechenov First Moscow State Medical University of the Ministry of Health of the Russian Federation, Bolshaya \\ Pirogovskaya str., 19/1, 119146, Moscow, Russian Federation \\ ${ }^{6}$ Kuban State Agrarian University named after I.T. Trubilin, Kalinina street 13, 350044, Krasnodar, Krasnodar region, \\ Russian Federation
}

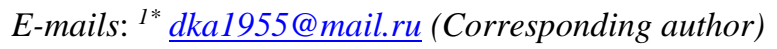

Received 12 February 2020; accepted 31 July 2020; published 30 December 2020

\begin{abstract}
World experience in economic development over recent periods indicates that, despite periodically occurring crisis situations, including globalization processes appearing all over specific countries, Such situations consistently develop on a more accelerated scale. Undoubtedly, the crisis situation that developed in the world market in the first half of 2020 under the influence of COVID-19 on all economies of countries without exception has had a great influence, and the nature of such an influence will certainly be felt over the next several years. In this vein, the establishment of the rules applicable in a particular jurisdiction regarding the activities of controlled foreign companies is one of the mechanisms for any state to protect its own national tax base. Using this approach, the modern rules of tax regulation of controlled foreign companies provide for the establishment of special rules for the shareholders, acting as controlling persons in terms of profits obtained from their foreign companies. At the same time, the application of tax exemptions to the profits of controlled foreign companies is undoubtedly one of the riskiest operations, despite the fact that a wide list of grounds for their application may be provided for within the specific state. As a result of a study of the activities of controlled foreign companies operating within the framework of national jurisdiction, when analyzing the degree of influence of tax bases, a strongly pronounced linear relationship with a correlation coefficient of -0.93 was revealed. This circumstance made it possible to identify the following important feature for controlled foreign companies: financial corporations are no longer attracted by the option of being in a specific national jurisdiction; moreover, they are more focused on other jurisdictions, including low-tax or offshore ones. The correlation analysis revealed a strongly pronounced linear relationship between the tax base and the tax rates; however, in terms of controlled foreign companies, which are primarily subject to national legislation, the correlation coefficient amounted to +0.89 , which characterizes the economic tendency to reduce their financial investments, despite the reduction of the actual tax rate. In turn, for controlled foreign companies, whose activities are regulated to a greater extent by foreign legislation, the correlation coefficient amounted to -0.93 , which is characterized by a reflection of the greater economic effect of actual tax rate reduction according to the following scenario: the tax rate reduction represents more financial injections for a particular national jurisdiction. At the same time, against the background of the quite consistent and successful in specific areas unification of EU tax rules, the problem of the incoherence of the rules concerning controlled foreign companies versus national jurisdictions of both
\end{abstract}




\section{ENTREPRENEURSHIP AND SUSTAINABILITY ISSUES}

ISSN 2345-0282 (online) http://jssidoi.org/jesi/ 2020 Volume 8 Number 2 (December) http://doi.org/10.9770/jesi.2020.8.2(2)

EU member states and other countries remains open and relevant. This circumstance contains controversial issues regarding the legitimacy of the application of the general regime of controlled foreign companies, since taking into account the fundamental economic freedoms, which, in particular, are enshrined in the OECD Model Double Taxation Convention on Income and Capital, the legitimacy of establishment of the internal rules of controlled foreign companies for various kinds of challenges, including Brexit, are sufficiently controversial.

Keywords: controlling person; tax base; income tax; income tax rate; national sovereignty

Reference to this paper should be made as follows: Khoruzhy, L.I., Karabasheva, M.R., Hajiyev, H. A., Zhadobina, N. N., Alekhina, N. A., Shichiyakh, R. A. 2020. Controlled foreign companies: influence on the sovereignty of the national tax base. Entrepreneurship and Sustainability Issues, 8(2), 33-50. http://doi.org/10.9770/jesi.2020.8.2(2)

JEL Classifications: H25, M42, M48

\section{Introduction}

The established procedure of doing business using the territories of several jurisdictions necessitates the state to pay close attention to the tax policy pursued not only in relation to corporate revenues within the jurisdiction. Attention should be paid to the taxation procedure when income is received by tax residents outside the country. This circumstance leads to a more detailed study of theoretical and practical aspects in the field of international taxation (Eshuis, 2014). At the same time, the consideration of cases of practical tax evasion through various international structures remains the indirect aspect. Consequently, this circumstance strengthens the need for a more detailed approach to study and procedure of reconciliation of the practical aspects of protection of the national tax base from its diversion (Aburto, 2007), taking into account the development of effective mechanisms to counter tax evasion, including the use of gray tax evasion schemes by foreign structures, etc.

In this regard, the establishment of rules (procedures) applicable in a particular jurisdiction regarding the taxation of controlled foreign companies (CFCs) is one of the mechanisms to protect their own national tax base. Using this approach, the state provides for the establishment of a taxation procedure for the shareholders (who are controlling persons) of a portion of the profits from their foreign companies (Sangiovanni, 2013). At the same time, a certain part of foreign companies may be outside the national jurisdictions using the preferential tax regimes (Grossule, 2020). Therefore, the procedure of doing business outside the national jurisdiction is not to a certain extent relevant for controlling persons when applying the provisions on CFCs, since the tax rules are leveled, and the tax obligations are equalized.

\section{Literature review}

There is an active interaction in the practical activities of the EU countries between fiscal authorities and tax fraud and tax evasion, as well as aggressive tax planning of the corporations. So, following the results of the 2013 meeting of the CFE fiscal committee (European Confederation of Tax Advisers) in Brussels, where the negative impact of fraudulent actions by taxpayers on the economies of the member states of the European Union was discussed, specific measures aimed at countering tax evasion were proposed (Aggarwal, 2011). This approach adequately indicates the increased attention of the entire world community to the financial situation within each country. Consequently, the states are uniting to stabilize the national economy and combat the "diversion" of the tax base and profits transfer (Hampl, 2020). Thus, the international taxation theorists Bertrand (2015) and Akamah (2018) proposed a general rule concerning CFCs, which to one degree or another is contained as separate elements of its definition: "if a company from one country is controlled by the persons who are simultaneously residents of another country and participants in this company, these persons will pay tax on all profits of this company, if this profit is transferred by them in order to avoid taxation". In this regard, the following conditions 


\section{ENTREPRENEURSHIP AND SUSTAINABILITY ISSUES}

ISSN 2345-0282 (online) http://jssidoi.org/jesi/ 2020 Volume 8 Number 2 (December) http://doi.org/10.9770/jesi.2020.8.2(2)

can be distinguished for recognition of a company controlled in accordance with the legislation on CFCs for the jurisdiction of each country:

1) the legal entity belongs to the foreign company (Arregle, 2016);

2) the company is controlled by a person who is a tax resident;

3) tax evasion is a goal pursued upon receipt of profit, which is subsequently transferred to a foreign company (Huang, 2018).

To the extent that three conditions are met simultaneously, the resident will be obliged to pay the foreign company income tax in the respective country (jurisdiction). This approach is also applied in the Russian tax legislation. In particular, as a rule, a foreign organization is recognized as a CFC when the following conditions are met simultaneously: the company is not recognized as a tax resident of the country's jurisdiction, while the controlling person of the company is a company and (or) an individual recognized as the tax resident of the country (Nigamaev et al., 2018; Sazanov and Akhmetshin, 2016; Garnov et al., 2020).

It should be noted that in the opinion of Turishcheva (2020), provision of a decisive influence or the ability to exercise a decisive influence on the decisions made by such a company when distributing the profit (income) after taxation due to direct or indirect participation in such a company, participation in the contract (agreement), the subject matter of which is the company management, or other features between the person and the organization and (or) other persons, is recognized as control over the company.

Since the general tax rules for the CFCs, in the opinion of Akhmadeev (2019) and Morozova (2019), are not fully developed, accordingly, the national legislation governing the procedure for taxation and control over the activities of the CFCs must comply with international principles and norms contained in international treaties and acts (Almunia, 2018). In this regard, it is important to analyze national legislation for its compliance with international principles. In particular, they include: the principle of legality, the principle of equality, the principle of freedom of economic activity, etc. As a rule, the practice of taxation in relation to CFCs is a special legal institution that takes into account the basic foundations of the problems of business structuring both in national jurisdiction and beyond its limits, including relations with offshore jurisdictions, preventing the national jurisdiction from lagging behind the application of international agreements and the exchange of tax information. In turn, the practical experience of application of the legislation on CFCs indicates the existence of various opinions of the economists Iurko (2018) and Arner (2020), pointing out the shortcomings of certain existing provisions. In particular, these shortcomings concern the established threshold for notification and income tax payment (Lehoux, 2019), the additional burden on businesses related to the translation of statements for national use (Kosov, 2016; Vertakova et al., 2019; Akhmetshin et al., 2019), and the absence of clearly established provisions distinguishing between revenues in various industry aspects (Bykanova, 2018; Rahman and Bobkova, 2016; Prodanova et al., 2019). To date, many issues have not been resolved, the legislation on CFCs in the framework of national regulation continues to be edited, amended, and improved (Petrova, 2019; Puryaev et al., 2019). In this regard, attention should be paid to the current procedure for determining CFCs, based on its criteria for individual states.

\section{Theoretical background}

In the international taxation practice, the general condition for the recognition of a person as a controlled one is the ability of the controlling person to influence it in any respect. At the same time, a legal standpoint involves the reservation on the attribution of the CFCs exclusively to the category of a foreign person. At the same time, the current procedure applied in most world countries in relation to CFCs recognizes a foreign legal entity (i.e., having a corporate form) and does not apply to their other forms, in particular, to foundations, trusts, etc.

It should be noted that in order to recognize a foreign company belonging to the CFC category, the current legal status of a state belonging to a particular jurisdiction is more applicable. This approach is used in countries such as the USA and Germany. The provisions of the OECD recommend the use of an expanded definition of the 
ENTREPRENEURSHIP AND SUSTAINABILITY ISSUES

ISSN 2345-0282 (online) http://jssidoi.org/jesi/ 2020 Volume 8 Number 2 (December) http://doi.org/10.9770/jesi.2020.8.2(2)

CFCs in national jurisdictions. This is no coincidence since in this case, the scope of taxation will be used in relation to permanent missions. Consequently, if a taxpayer receives additional profit using permanent missions outside of national jurisdiction, the state will additionally receive budget revenues, taking into account the establishment of fair income tax rates and compliance with tax principles.

The definition of the CFCs is inextricably linked with the definition of tax residency. Moreover, the tax residency of companies and structures can be determined in various ways. In particular, states can recognize companies as foreign using both a formal criterion (existence of a place of incorporation of a company in a foreign state) or based on an expanded approach, for example, when establishing the role and place of the central government in a particular jurisdiction. In particular, the current German tax law contains a condition for the recognition of a foreign company as a controlled one. For this purpose, it must be registered in a foreign country in which the office is physically located and the company is managed. At the same time, a company is recognized as a tax resident of Germany if physically its office or its management is located in Germany. Respectively, the provisions of the internal legislation on CFCs are not applicable to this category of taxpayers.

In turn, from a legal standpoint in the UK, a stepwise approach is applied when classifying a company as a CFC. At the first stage, the company is tested on the basis of its place of residence in the relevant national jurisdiction. In the event that the company is registered in the United Kingdom, and its place of business is in another territory (outside its location), and such a person pays taxes, taking into account the nature of the effect of double taxation avoidance agreements, the fundamental value in determining the CFC will be the amount of income received in a specific jurisdiction. In this case, the amount of income received for the tax period must be at least $50 \%$ of the total. Directly, in the practice of taxation, disputes arise between taxpayers and tax authorities regarding the procedure of the place of residence of the CFC. In this regard, prominence should be given to the following criteria for the recognition of CFCs (Fig. 1).

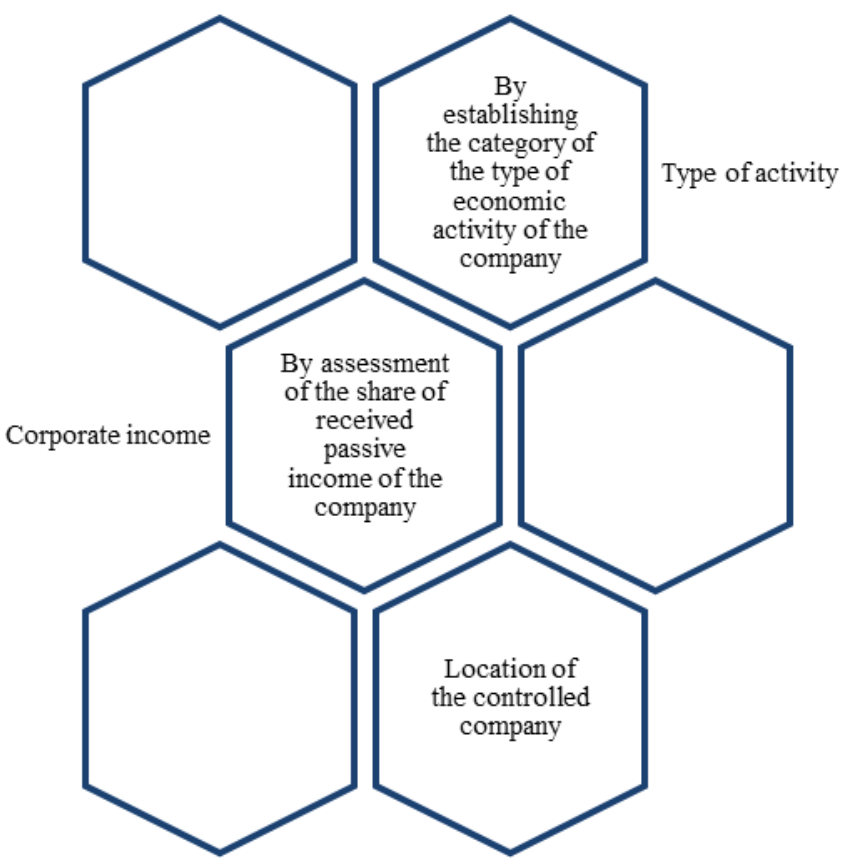

Figure 1. Basic criteria for compliance with the recognition of the CFC Source: compiled by the authors 


\section{ENTREPRENEURSHIP AND SUSTAINABILITY ISSUES}

ISSN 2345-0282 (online) http://jssidoi.org/jesi/ 2020 Volume 8 Number 2 (December) http://doi.org/10.9770/jesi.2020.8.2(2)

It should be noted that when determining the location of a company to meet the criteria of the CFC, the states form special registers at the legislative level that correspond to different jurisdictions. In particular, the states or certain (offshore) territories that do not carry out the fair competition and are not included in the current procedure for mutual tax exchange of information between fiscal authorities in relation to both taxpayers and their transactions may be included in the illegal environment.

Special attention should be paid to the formation by the states of a separate list of jurisdictions, in which reduced tax rates are applied or the companies are completely tax exempt; therefore, in this case, the CFC taxation procedure may be justified from the point of view of obtaining additional tax revenues to the budget (Korableva et al., 2018). In addition to the criteria-based approach to the recognition of the persons attributable to CFCs, an important aspect is the current procedure for their profit taxation. In this case, the established procedure for calculating the taxable amount of profit, taking into account the legal qualifications of the transaction, is the most significant.

In general, the obtained value of the profit of the CFC shall be included in the tax base of the controlling person or in proportion to its participation or control. This taxation procedure is applied in most countries. Moreover, in most cases, the tax law of states contains significant elements of provisions that exclude the application of the general procedure for CFC taxation. However, an important aspect in taxation, in particular in Spain, Germany, and the USA, is the observance of "deminimis". This involves the cases when, in the calculation of the income received, the CFC is restricted to the limit of the established threshold values. In establishing the legal qualifications of a transaction in relation to the profits received by the CFC, the following concepts are applied:

1) the recognition of actual profit as the value of "supposed" dividends (fictitious distribution of profits);

2) the identification of the actual amount of profit in respect of the controlled person.

In this regard, when the taxpayer chooses the appropriate version of the concept, it will lead to the application of the legally established tax rules for the CFC, taking into account the current tax rates. At the same time, from the standpoint of tax administration rules, most states have a clear establishment of the procedure for annual notification by the taxpayers of the presence of CFCs on the basis of the presentation of established forms, as well as the procedure for providing grounds for exemption of the CFC's profits from taxation.

\section{Data analysis}

When considering the procedure for presenting the grounds for exempting the CFC's profits from taxation, taking into account the current taxation procedure, attention should be paid to the general list containing the conditions for their provision. Moreover, if at least one of the following conditions can be attributed to a specific CFC, then its profit is exempt from taxation on the basis of the general conditions provided in Figure 2. 


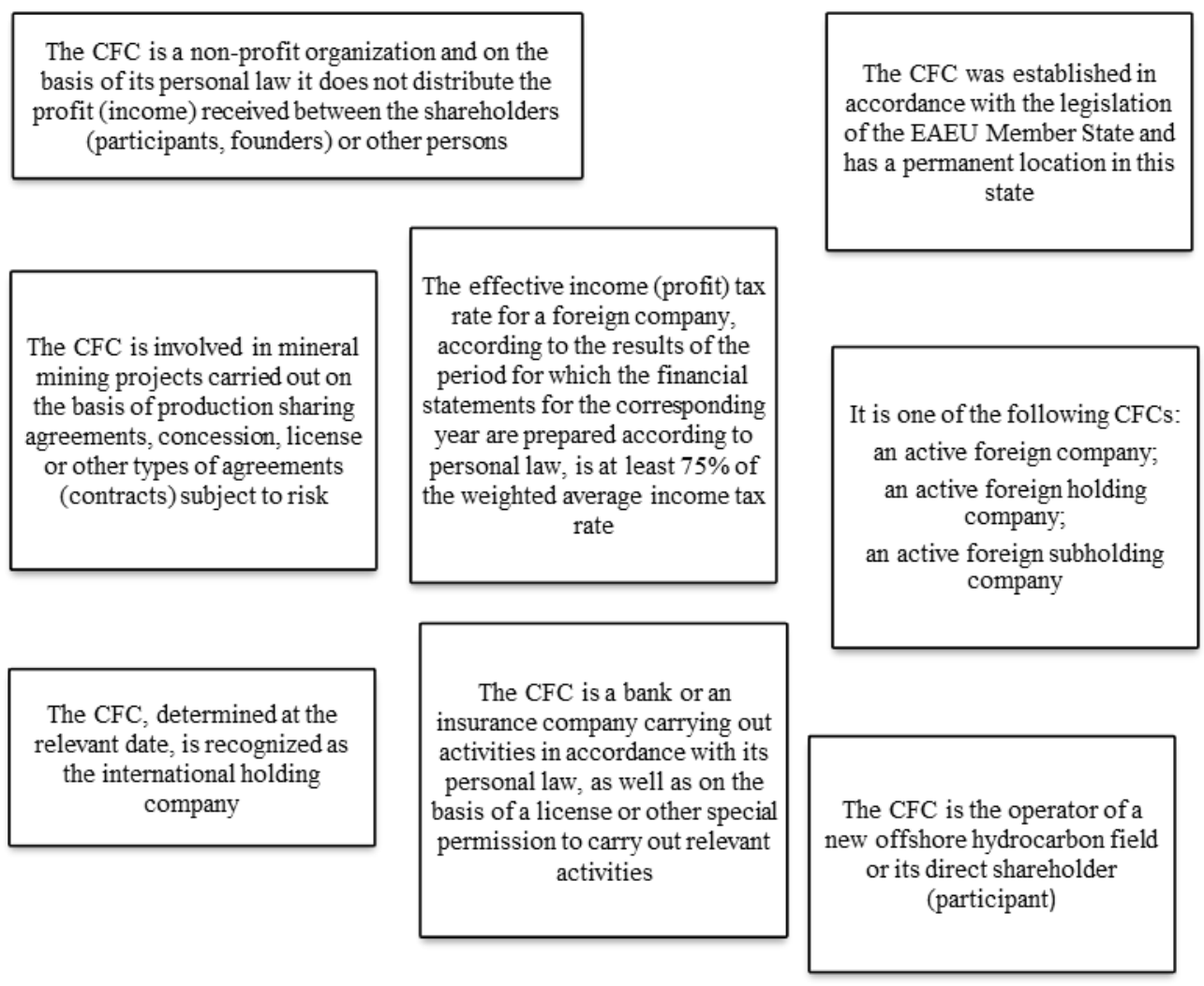

Figure 2. Basic principles of the application of exemption from taxation of profits of the CFC by the example of national tax jurisdiction

Source: compiled by the authors

It should be noted that in order to exempt the CFC from taxation, it is also important to comply with the provisions regarding the legal aspects of circulating bonds and debt obligations and the mandatory presence of a valid international treaty in the field of taxation with an appropriate exchange of information established for these purposes between the national tax jurisdiction and the state in which the CFC is located on a permanent basis. This is the key condition for exemption of the CFC from income taxation.

When the CFCs participate in relevant mining projects, the following should be observed as a basis for granting tax exemption: the CFC is one of the parties to the contract, including: concession, license, as well as on the basis of production sharing agreement, or other types of contracts based on risk conditions. In this case, the foreign state (territory) or the government, as well as an institution authorized by it (for example, a state corporation) should be the other side of the concluded agreements. At the same time, there is an additional condition in the tax law regarding the application of the CFC income tax exemption: the share of income received in connection with participation in agreements for the period of preparation of financial statements for a financial year should be more than $90 \%$ of the total CFC income, as well as if there are no incomes for the relevant period in the financial statements, or consist of the amount of income in the form of exchange differences received or income not accounted for by their individual types, taking into account tax legislation.

It should be noted that the general terms and conditions of the tax law for exemption of the CFC from income taxation contain a closed list. If the CFC does not fit one of the criteria, then the controlling person is obliged to 


\section{ENTREPRENEURSHIP AND SUSTAINABILITY ISSUES}

ISSN 2345-0282 (online) http://jssidoi.org/jesi/ 2020 Volume 8 Number 2 (December) http://doi.org/10.9770/jesi.2020.8.2(2)

pay tax on the profit received by the corresponding CFC. In order to apply tax exemption for any of the above reasons, the controlling person must submit to the tax authority at the place of location the documents confirming compliance with the conditions for exemption, translated into the national language of the jurisdiction in the part required for verification, together with the CFC notification in a timely manner. According to written explanations of the Federal Tax Service of Russia, the following is a valid list of supporting documents:

1) tax reporting of the CFC (Lehoux, 2018);

2) calculation of the effective income (profit) tax rate of the CFC and the weighted average corporate tax rate;

3) certificate of tax residence of the CFC for the corresponding period.

In juridical doctrine, the scope of application of exemption for CFCs' profits from taxation is considered one of the riskiest. Despite the fact that the legislative level provides a wide list of grounds for the exemption from taxation of the CFC's profits, in practical terms, there are a number of problems in the application of legal grounds. First of all, the taxpayers are required to calculate the effective tax rate in the country of their location equal to at least $75 \%$ of the Russian average weighted income tax rate. At the same time, according to the findings of Carruthers (2020), there is a contradictory opinion in the practical activity of controlling persons. For example, if such a person located in Germany applies a basic tax rate of more than $20 \%$, then, when calculating the weighted average, the excess of $75 \%$ of the $20 \%$ income tax rate in national jurisdiction will be $75 \% \approx 15 \%$. Therefore, if the current tax rate in the country of location is approximately $15 \%$, in this country the general income tax rate will be approximately the same number of percent, therefore, it is possible to apply exemption for such a company (Lampert, 2013). At the same time, the logic of such reasoning lacks the essential detail - the rate should be "effective". For example, in Switzerland, a different procedure is applied to provide benefits to individual companies, and the performance criterion is less than $15 \%$ (Seo, 2020).

Another controversial practical aspect is related to the exemption grounds for active foreign companies with passive income of at least $20 \%$ of their total income, or to subholding companies. The attention should be paid to the fact that tax legislation does not contain a definition of the "active income" concept. It may be advisable to follow logically from the opposite, i.e. to define it through the concept of passive income, and, which is extremely important, through the unclosed list of features. One way or another, the above legal norm contains standard varieties of passive income, including: interest, dividends, income from shares, income from the sale of shares in shares, income in the form of a liquidation premium, and royalties. It should be understood that if royalties with interest in aggregate account for more than $80 \%$ of the company's income, then such a company is not automatically considered an active foreign company; therefore, its profit is subject to income taxation according to the rules of national jurisdiction.

The list of such expense as the certain types of passive income, in particular, the income from the provision of services (more related to $\mathrm{R} \& \mathrm{D}$, as well as development, research in the scientific field, marketing promotion services), rent, etc., may be open, and the main danger lies in the current wording "other ... similar income". Therefore, the tax risk lies in the fact that even if the CFC is engaged in the provision of any of the services mentioned above, for example, related to scientific studies of the activity of the drug, which then can lead to the sale of this drug in the territory of national jurisdiction, then anyway the fact of obtaining income from research activities may lead to the qualification of this income as passive, and here the legislatively established percentage boundaries should be taken into account.

Moreover, the amount of passive dividends that are not included in the calculation of income excluded on the basis of the granted exemption of the active foreign subholding companies relates to income from active foreign companies. At the same time, in this situation, the residents do not belong to foreign companies. Consequently, a resident acting as a subsidiary of a Cypriot organization will not meet the characteristics of an active foreign 


\section{ENTREPRENEURSHIP AND SUSTAINABILITY ISSUES}

ISSN 2345-0282 (online) http://jssidoi.org/jesi/ 2020 Volume 8 Number 2 (December) http://doi.org/10.9770/jesi.2020.8.2(2)

company. Therefore, the indicated exemption will not be applicable if the dividends are received from the operating companies of national jurisdiction as the main income of a foreign company, therefore, the taxpayers have the right to defend their interests in court.

\section{Analysis of the practice of tax regulation of legal acts in the EU countries}

In the analytical part of the scientific study, it is important to analyze the existing problems arising from the legal regulation of the taxation of the CFCs in the countries of the European Union, based on the analysis of judicial practice, especially vivid, notable court decisions. Given the imbalance due to differences in existing EU law and the general rules governing CFC taxation (Gidirim, 2016), the case law of Cadbury Schweppes plc and Cadbury Schweppes Overseas Ltd v Commissioners of Inland Revenue should be reviewed. The precedent for the tax dispute is the following practical situation: the confectionery company Cadbury Schweppes (now in civil circulation under Cadbury plc) with a head office in London (the parent company) has established a number of subsidiaries in Ireland. However, these companies carried out financial activities without having an office or a staff of employees and also with no telephone communications. At the same time, in 2006, Ireland had a tax incentive that established a reduced tax rate of $10 \%$ of the company's profits, while in the UK the main tax rate was at least 30\%. Thus, Cadbury Schweppes, in fact, carried out a tax optimization of its business.

The UK tax authorities, acting as the plaintiff, raised the issue of application of the CFC rules to the subsidiaries. In turn, Cadbury Schweppes, acting as the defendant, referred to economic freedoms within the framework of the EU Member States in the course of the lawsuit. At the same time, the judicial authorities accepted the defendant's position, noting the incorrectness of considering the level of taxation as the application of criteria to resolve the controversial issue of the applicability of the CFC rules within the EU. At the same time, as noted in the court decision, there is a situation in which it is possible to limit the entrepreneurial freedom of the company in the event of imitating economic activity and provided that the sole purpose is intentional tax evasion. In this regard, the position of the court is among the precedents in the field of international practice of CFC taxation.

Another landmark court decision for the EU in the field of research issues is the case "Vodafone 2 v. RCC". First of all, it is worth noting that Vodafone was (and is for the current tax period) one of the largest mobile operators. The case was heard in British and European courts. Initially, Vodafone sued for suspension of additional verification of the tax return. Its subsidiary was located in Luxembourg, and UK tax authorities were exploring the feasibility of applying British internal CFC tax rules. In turn, Vodafone referred to the case-law of Cadbury Schweppes and tried to prove that the CFC rules are applicable only in the case of circumvention or deliberate fraud of the tax system using various schemes. At the same time, the court of appeal agreed with the plaintiff Vodafone, taking into account the precedent and, thereby, confirming the conclusions about the inapplicability of the internal rules of the CFC to the CFC established and operating in another state. However, the court's opinion was narrower than the conclusions drawn in the Cadbury Schweppes case. So, from the standpoint of the judges, not all CFC incomes are subject to protection against taxation, but only in terms of the value added by the employees. Thus, the British court set itself a broader task: to correlate the findings of the Cadbury Schweppes precedent with the answer to the question of the possibility of exemption from the CFC rules at the level of the parent company of a subsidiary established within the EU. Having identified such a contradiction, the judges formed the following scenarios:

(1) to return the case again to the European Court, or

(2) to upgrade the existing CFC regulations (Delgado, 2017).

The correctness of the entrepreneurial freedom violation on the basis of counteraction to tax evasion is the key problem of European legal doctrine. As a rule, the Cadbury Schweppes case and the similar Columbus Container Services BVBA \& Cov. Finanzamt Bielefeld-Innenstadt case is analyzed. It follows from the first of these cases that in the EU it is quite natural that the company seeks to optimize its operations in order to find a lower tax rate. 


\section{ENTREPRENEURSHIP AND SUSTAINABILITY ISSUES}

ISSN 2345-0282 (online) http://jssidoi.org/jesi/ 2020 Volume 8 Number 2 (December) http://doi.org/10.9770/jesi.2020.8.2(2)

However, these actions do not indicate tax evasion (Yemelyanov et al., 2019). At the same time, the court needs to find out whether the CFC actually carries out the entrepreneurial activity in the country of its incorporation. The answer to this question depends on the resolution of the basic question of the applicability of the internal rules of the CFC profits taxation. As for the second of these trials, here the court evaded a direct answer to the analyzed question, thereby making narrower the analysis of the fact of discrimination. Therefore, this lawsuit did not become a precedent in deciding which of the tax principles prevails: territorial or global (Monsenego, 2012). Thus, it is important to focus on the identified and relevant for the EU problem of the applicability of the internal national taxation rules for the CFC, which operates and is incorporated in the EU member state, but not at the place of incorporation or operation of the parent company. At the same time, there are other precedents in international legal practice that gives rise to unresolved issues, since the specifics of the current EU regulatory legislation in a particular state are not fully taken into account.

\section{Results}

Based on the example of one of the jurisdictions, let us carry out a correlation analysis of the tax base and tax rates, the results of which will make it possible to conclude that they are dependent. For the purposes of the study of the specifics of the CFC taxation, taking into account the current provisions of the Tax Code of the Russian Federation, regulating the procedure for accounting for the profits of CFCs in a general manner, non-operating incomes were also included in the composition of the income received. This procedure is general in tax base calculation for income tax for the taxpayers and Russian companies. In this case, the date of income to determine the CFC's profit is the end date of the period for which financial statements for the financial year are prepared on the basis of the law of the location (registration) of the unincorporated foreign company or structure (hereinafter the UFC). In the event that the date can be determined by the personal law of the CFC, the date of receipt of income is recognized on December 31 of the year following the current tax period. If the personal law of the CFC does not imply an obligation to provide financial statements, the date of recognition of income will be December 31 of the current tax period, the last of which is the end date of the corresponding financial period.

In this regard, with the entry into force of tax legislation in 2015, in general, 2016 became the first year for the taxpayers to include the CFC's profit in the tax base, with mandatory inclusion of the CFC's profits for 2015, if the personal law of such a company required the preparation of a financial report for the current tax period. In particular, the annually updated tax return on income tax for the period of 2019 when calculating the income received in the form of profits of the CFC includes a separate appendix containing detailed transcripts by categories of taxpayers (Fig. 3). 


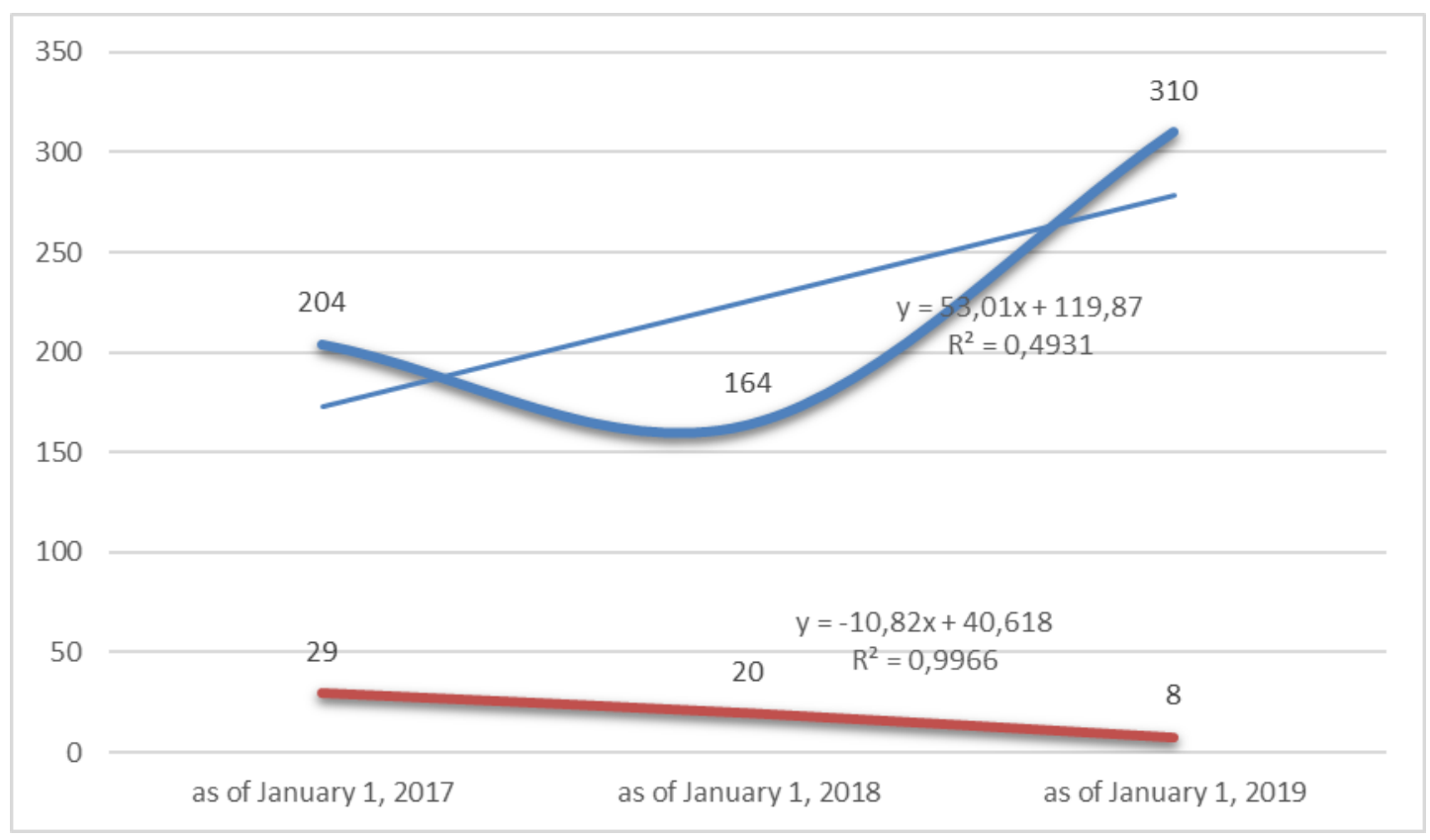

Figure 3. Comparative dynamics of CFC activities in national jurisdictions in calculating the number of companies to the tax base Source: The authors' research based on the data of https://www.nalog.ru/rn77/related_activities/statistics_and_analytics/forms/

It should be noted that when studying the average for the tax period number of CFCs operating under the personal law as of January 1, 2018, it decreased to 164 units, and over the next tax period the growth was 310 units.

In this case, the physical volume of the growth rate of the tax base as of January 1, 2019, compared to the same period as of January 1, 2017, was 32\%, and the increase in the number of the CFCs operating under personal law for similar periods was 52\%. The results obtained on the basis of the analysis of the influence of the tax bases on the CFCs under study showed a strongly pronounced linear relationship with a correlation coefficient equal to 0.93 .

This approach is characterized by the following important circumstance: financial corporations are no longer attracted by the option of being in a national jurisdiction, and they focus more on other jurisdictions, including low-tax or offshore ones.

In turn, the dynamics of the number of the CFCs operating according to the rules established by national legislation showed a negative trend. At the same time, with regard to determining the tax base of controlling persons for the income in the form of profit received, the basic tax rate of $20 \%$ is applied. However, the tax base for calculation does not include the expenses received from other activities and the amount of losses incurred in relation to the activities of the controlling entities themselves. Moreover, the entire amount of the calculated tax is subject to transfer to the federal budget, without its distribution as for the main category of taxpayers. This involves payment of $3 \%$ of the income tax to the federal budget and $17 \%$ of profit payable to the budgets of the subject of the Russian Federation. The following documents are recognized as supporting and confirming the value of the calculated tax base and calculated tax:

1) the income tax return and its annexes;

2) the financial statements of the CFC for the relevant period and the audit report on these statements. 


\section{ENTREPRENEURSHIP AND SUSTAINABILITY ISSUES}

ISSN 2345-0282 (online) http://jssidoi.org/jesi/ 2020 Volume 8 Number 2 (December) http://doi.org/10.9770/jesi.2020.8.2(2)

At the same time, this procedure is justified either by personal law or by constituent documents, in which a mandatory audit is established, including on a voluntary basis. Moreover, such documents of a foreign company must be translated into Russian.

In addition, certain clarifications of the Ministry of Finance of Russia contain an additional indication that the following can be used as supporting documents: the extracts from the CFC settlement accounts, primary documents confirming the operations performed in accordance with the company's business practices, etc. It should be noted that in relation to confirmation of the amount of the CFC profit received by the foreign entity the following provision is a general trend. If the Russian Federation does not conclude an international tax treaty with a specific country, then supporting documents must be certified by the competent tax authority of the respective country. In turn, when submitting supporting documents to the Russian tax authorities in a general manner, there is no obligation to notarize or apostille them. At the same time, an important condition in the evolution of accounting for the criterion indicator of profit received by the CFC in determining the tax base and the corresponding tax amount for 2015 and 2016 was the establishment of a threshold value for the tax period of more than 400 thousand euros, and a decrease in the minimum value up to 140 thousand euros in subsequent periods. Moreover, in order to determine the sum criterion, the amount of dividends paid on such a controlled company (distributed profit) is not taken into account. At the same time, if the minimum value of the sum criterion has not been exceeded, information on the amount of profit (loss) received on the CFC must be presented in the income tax declaration.

It should be noted that if the minimum size of threshold values is not exceeded by the CFC, the tax return must be filled in according to the simplified procedure, and in the case of loss, this provision cannot be applied. When identifying the features of the procedure for calculation and payment of the CFC's income, it is important to pay attention to the procedure for such an option when CFCs are registered in offshore jurisdictions.

In this case, using a general approach, the taxpayers either determine the profit received by the CFC on the basis of the financial statements within the same financial year of the company or carry out the calculations based on the provisions of the Tax Code of the Russian Federation. In this case, the rules apply to legal entities operating in the country. Therefore, if such CFCs are registered in offshore jurisdictions and the information on them does not contain data on the submitted statements, in this case, the controlling person is obliged to apply the provisions of the Tax Code of the Russian Federation. Thus, for such cases, there is no right to choose.

It should be noted that, as a general rule, the selected method of calculation and payment of the CFC income involves the actions of the taxpayer, namely: recording in the accounting policy for taxation purposes (for Russian organizations) and application to a specific CFC for at least five subsequent calendar years (tax periods). As a general rule, the accounting policy of the company for taxation purposes should contain an approved list of primary documents, on the basis of which the size of the CFC profit is calculated if they are applicable to the provisions of the Russian tax law and the company does not have financial statements. At the same time, on the practical side of the issue, such regulation of the list seems appropriate: the taxpayer can subsequently remove potential risks in demanding by the fiscal authorities of the documentation that is not used in principle in this CFC.

At the same time, tax legislation also provides for a reduction in the amount of the tax calculated in relation to the income received by the CFC. In these cases, it is subject to reduction in proportion to the share of the controlling person by the amount of the calculated tax amount in relation to:

1) income received (in relation to the Russian and foreign legal field of law);

2) income received of the permanent representative office of the CFC located in the Russian Federation. 
The study of the growth rate of the tax base and the calculated amount of tax payable to the budget in relation to the profits received by the CFC to the budget of the Russian Federation was conducted on the basis of statistical data of the Federal Tax Service of Russia for the tax periods 2016-2018 (Fig. 4).

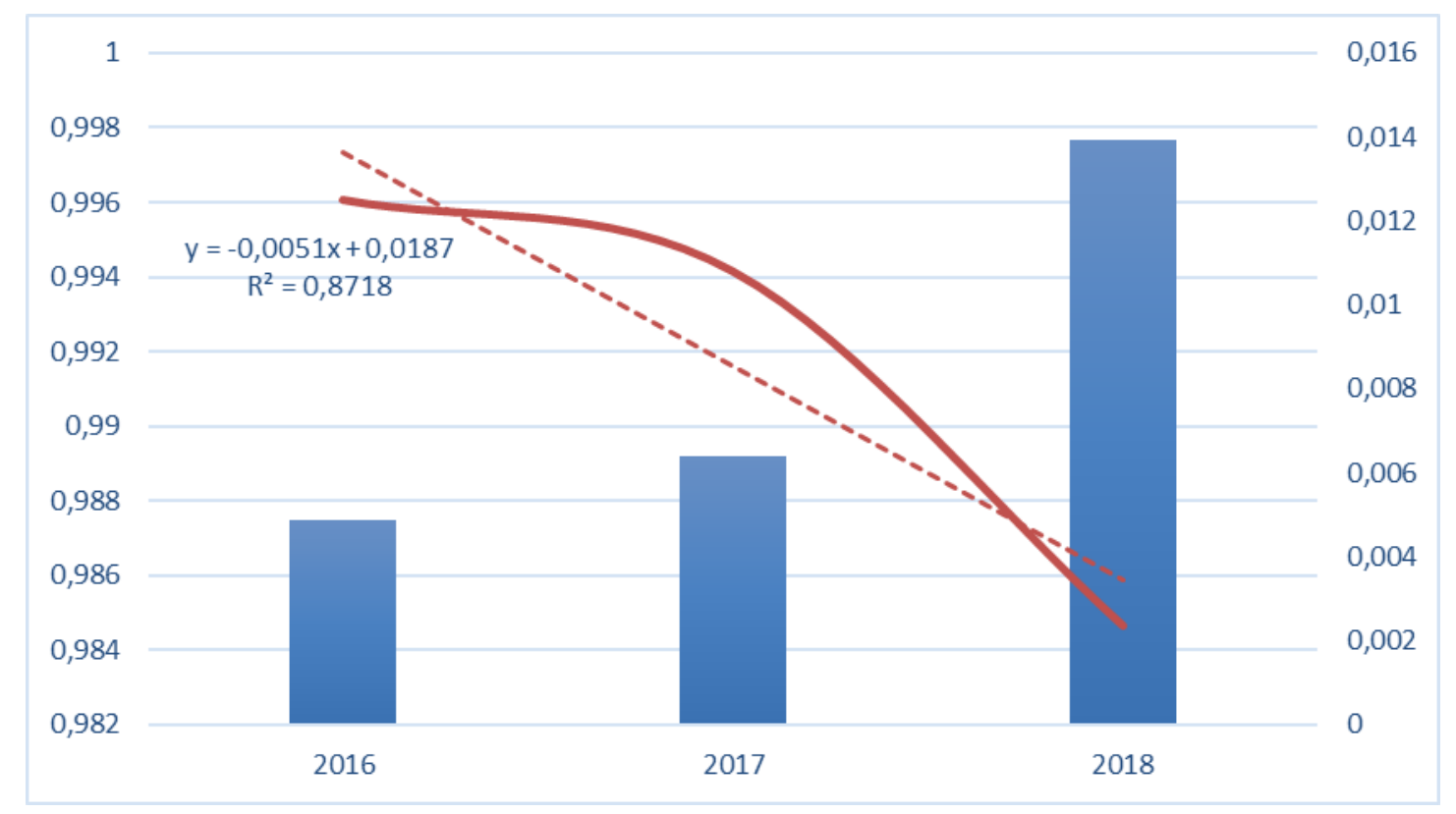

Figure 4. Comparative characteristics of the growth rate of the tax base and the amount of tax payable to the budget in relation to the CFC income payable

Source: The authors' research according to (nalog.ru, 2020)

The analysis of statistical data for the tax periods of 2016-2018 made it possible, based on a comparison of the tax bases for calculation of the CFC tax and tax payable, to determine the actual tax rate in the following limits:

- for the CFCs, the income of which is determined according to financial reporting compiled by their personal law:
$\checkmark 6 \%$ for 2016 ;
$\checkmark \quad 7 \%$ for 2017 ;
$\checkmark 5 \%$ for 2018 ;

- for the CFCs, the income of which is determined by the rules of national law:

$$
\begin{array}{ll}
\checkmark & 20 \% \text { for } 2016 ; \\
\checkmark & 18 \% \text { for } 2016 ; \\
\checkmark & 17 \% \text { for } 2016 ;
\end{array}
$$

A correlation analysis revealed a strongly pronounced linear relationship between the tax base and the tax rates; however, in the case of CFCs, which are primarily subject to national legislation, the correlation coefficient was +0.89 , which characterizes the economic trend towards a reduction in financial investments, despite the decrease in the actual tax rate. In turn, for CFCs, whose activities are regulated to a greater extent by foreign legislation, the correlation coefficient amounted to a value of -0.93 , which is characterized by a reflection of the greater economic effect of lowering the actual tax rate in the following scenario: a reduction in the tax rate represents more financial injections into the national jurisdiction. 


\section{ENTREPRENEURSHIP AND SUSTAINABILITY ISSUES}

ISSN 2345-0282 (online) http://jssidoi.org/jesi/ 2020 Volume 8 Number 2 (December) http://doi.org/10.9770/jesi.2020.8.2(2)

\section{Discussion}

First of all, it should be noted that, as part of a scientific study, one of the important tasks is to understand the theoretical aspects and practice in the specifics of supranational legal regulation of CFCs' income taxation in the countries of the European Union (Gootjes, 2020). At the same time, for quite a long time, there has been a clear tendency in the legal regulation in the field of taxation in the EU member states aimed at phasing out tax sovereignty within the framework of the united pan-European doctrine and economic community, represented primarily by transnational corporations (Baudot, 2020).

At the same time, at the level of the opinions of individual economists such as Kneller (2014) and Hathikal (2020), the recommendations contained in scientific studies in the form of separate proposals for establishing special tax regimes for certain categories of taxpayers in those EU member states in which the current maximum corporate income tax rates exceed their average values were repeatedly presented. In particular, such states include Austria and Belgium. This circumstance can be considered as a pronounced tax competition regarding the application of direct taxes in the EU member states (Linaa, 2020).

At the same time, the general approach to harmonization in the EU countries relates mainly to indirect taxation (Thanou, 2020). Accordingly, the current direct taxes are incorrectly attributed to them. At the same time, from a legal point of view, the current fact of a particular country's membership in the EU fully contains the obligations to formulate the norms of national tax legislation, including the scope of regulation of corporate taxation in relation to the CFCs (Biggeri, 2017). In this regard, the adoption of a package of regulatory legal acts by the European Commission in 2016 was characterized by a desire to build a unified system of corporate taxation. In this regard, it can be noted that this circumstance is fully similar to the current order of practical experience in building an indirect taxation system, and above all, VAT. In this regard, it can be noted that over the past few years, the pan-European course on tax integration is aimed at:

1) the functioning of a single consolidated corporate tax base (Nakamura, 2018);

2) taking into account the current OECD recommendations regarding the application of the provisions on BEPS (base erosion and profit shifting) (Majumder, 2020), which is also guaranteed by the taxation of the profits of the CFC subject to a number of conditions.

It should be noted that after the formation of a specific Brexit policy, the issues of general tax integration began to be more widely discussed, including the elements of legal emphasis (Perrone, 2020), taking into account the positive adoption of existing rules by the EU member states (Gozubuyuk, 2020). The reason for this policy was a peculiar approach from the UK, which conditionally agreed with the main motive of the BEPS plan, but rejected the general tax integration with the EU member states.

\section{Conclusion}

Based on the results of the study, it can be concluded that, in general, the current path for the development of tax legislation in most countries is typical from the perspective of the current legal regulation of CFCs. At least, three directives of the Council of the European Communities (EU Council) should be noted which are currently the legal tools for the legal regulation of the CFCs. First of all, the effect of EU Council Directive 90/435/EEC should be mentioned, which includes provisions that are characteristic of the entire taxation system of parent companies of EU member states and their subsidiaries. At the same time, on the basis of this directive, the tax on dividends for such organizations was canceled. In turn, the practical application of the EU Council Directive 2009/133/EEC, which replaces the previously effective Directive 2003/49/EU, taking into account the existing provisions, is aimed at the transfer of assets and the exchange of shares of companies that are tax residents of several national jurisdictions within the EU. At the same time, in terms of the application of the CFC, the effect of the Council 


\section{ENTREPRENEURSHIP AND SUSTAINABILITY ISSUES}

ISSN 2345-0282 (online) http://jssidoi.org/jesi/ 2020 Volume 8 Number 2 (December) http://doi.org/10.9770/jesi.2020.8.2(2)

Directive 2003/49/EC should be mentioned, on the basis of which all processes related to the taxation of interest and royalties paid by associates within the jurisdiction of the EU countries use a direct prohibition on taxation directly in relation to the intragroup calculated amounts of interest and royalties, as well as the payments made on dividends. Meanwhile, the current EU legal doctrine, under the influence of Brexit, in the medium term can influence the adoption of additional directives in the field of corporate taxation, since it is the United Kingdom that remains a key financial center of the EU, where an unprecedented (on the EU scale) amount of the CFCs operate, which in turn provide direct investment in the EU, and therefore make a significant share in the form of foreign direct investment in the EU (Permikin, 2018). Thus, taking into account the circumstances, the following situation may arise in the practice of international taxation: a European subsidiary paying dividends (or interest) to the parent company operating in the UK. The following practical aspect arises: the ability or inability of such a company to refer to existing directives in order to exempt the dividends from taxes. It should be understood that in the case of a positive answer to the question, the problem of double taxation of the amount of dividends received (or interest payments, or royalties) both from the UK in the EU and vice versa under the Brexit conditions arises. This problem is the most vulnerable since the tax period of 2021.

Further, it is important to pay attention to the following fact. Against the background of the unification of tax rules in the EU, which is quite consistent and successful in specific areas, the issue of inconsistency of the rules of $\mathrm{CFCs}$ in the national jurisdictions of the EU member states remains unresolved. This fact raises a challenging and quite logical question: if the EU has a common economic and legal space, then how legitimate is the application of the general CFC regime, since taking into account fundamental European economic freedoms, which, in particular, are enshrined in the OECD Model Double Taxation Convention on Income and Capital, the admissibility of the CFC internal rules to various external challenges within the EU is a controversial practical issue. Nevertheless, the state is trying to bridge the current gap in the practical plane of taxation. In particular, in 2015, a special Report "Designing Effective Controlled Foreign Company Rules" was adopted. These rules contain a provision on the need to develop the uniform, unified CFC rules while preserving the freedom of the EU member states to develop their own provisions that take into account national specifics. At the same time, a uniform approach in the field of legal regulation of CFCs in the EU countries is manifested in most of its states on the basis of provisions that define (1) the concept of CFCs, and (2) the controlling person, as well as (3) the procedure for determination and imposition of such CFC income. In the authors' opinion, this approach will contribute to the preservation of the sovereignty of the tax bases.

\section{References}

Aburto, L. \& Weber, R. (2007). Improved supply chain management based on hybrid demand forecasts. Applied Soft Computing, 7(1): 136-144. https://doi.org/10.1016/j.asoc.2005.06.001

Aggarwal, R., Erel, I., Ferreira, M., \& Matos, P. (2011). Does governance travel around the world? Evidence from institutional investors. Journal of Financial Economics, 100(1): 154-181.

Akamah, H. T., Hope, O.-K., \& Thomas, W. B. (2018). Tax havens and disclosure aggregation. Journal of International Business Studies, 49(1): 49-69.

Akhmadeev, R.G., Bykanova, O.A. \& Salomadina, P.S. (2019). The effect of the VAT change on the final consumer. Proceedings of the 33rd International Business Information Management Association Conference, IBIMA 2019: Education Excellence and Innovation Management through Vision 2020, 765-770.

Akhmetshin, E. M., Plaskova, N. S., Iusupova, I. I., Prodanova, N. A., Leontyev, A. N., \& Vasilev, V. L. (2019). Dataset for determining rational taxation value with incompatible criteria of economic efficiency and equity. Data in Brief, 26 https://doi.org/10.1016/j.dib.2019.104532 


\section{ENTREPRENEURSHIP AND SUSTAINABILITY ISSUES}

ISSN 2345-0282 (online) http://jssidoi.org/jesi/ 2020 Volume 8 Number 2 (December) http://doi.org/10.9770/jesi.2020.8.2(2)

Almunia, M. \& Lopez-Rodriguez, D. (2018). Under the radar: The effects of monitoring firms on tax compliance. American Economic Journal: Economic Policy, 10(1): 1-38. https://doi.org/10.1257/pol.20160229

Arner, D.W., Buckley, R.P. \& Zetzsche, D.A. (2020). Sustainability, FinTech and Financial Inclusion. European Business Organization Law Review, 21: 7-35 https://doi.org/10.1007/s40804-020-00183-y

Arregle, J. L., Miller, T. L., Hitt, M. A., \& Beamish, P. W. (2016). How does regional institutional complexity affect MNE internationalization? Journal of International Business Studies, 47(6): 697-722. https://www.jstor.org/stable/43907604

Baudot, L., Johnson, J.A. \& Roberts, A. (2020). Is Corporate Tax Aggressiveness a Reputation Threat? Corporate Accountability, Corporate Social Responsibility, and Corporate Tax Behavior. Journal of Business Ethics, 163: 197-215. https://doi.org/10.1007/s10551$\underline{019-04227-3}$

Bertrand, O. \& Capron, L. (2015). Productivity enhancement at home via cross-border acquisitions: The roles of learning and contemporaneous domestic investments. Strategic Management Journal, 36(5): 640-658. https://doi.org/10.1002/smj.2256

Biggeri, L., Ferrari, G. \& Yanyun, Z. (2017). Estimating cross province and municipal city price level differences in China: some experiments and results. Social Indicators Research, 131(1): 169-187. https://doi.org/10.1007/s11205-016-1238-0

Bykanova, O.A., Akhmadeev, R.G., Glubokova, N.Y. \& Kravchuk, I.S. (2018). The global market of roundwood: Financial aspects. Bulgarian Journal of Agricultural Science, 24(1): 8-16. https://www.agrojournal.org/24/01-02.pdf

Carruthers, B.G. (2020) Law, governance, and finance: introduction to the Theory and Society special issue. Theory and Society, 49: 151164. https://doi.org/10.1007/s11186-020-09390-5

Delgado, M. S. \& McCloud, N. (2017). Foreign direct investment and the domestic capital stock: The good-bad role of higher institutional quality. Empirical Economics, 53(4): 1587-1637.

Eshuis, J., E.-H. Klijn \& Braun, E. (2014). Place marketing and citizen participation: Branding as strategy to address the emotional dimension of policy making? International Review of Administrative Sciences. 80 (1): 151-171.

Garnov, A. P., Garnova, V. Y., Prodanova, N. A., Khudyakov, S. V., \& Zatsarinnaya, E. I. (2020). Digitalization of the economy: Problems and prospects. Journal of Critical Reviews, 7(7): 442-444. https://doi.org/10.31838/jcr.07.07.76

Gidirim, V.A. (2016). Basics of international corporate taxation. Person of the word, 1(2): 91-102.

Gootjes, B., de Haan, J. \& Jong-A-Pin, R. (2020). Do fiscal rules constrain political budget cycles?. Public Choice. https://doi.org/10.1007/s11127-020-00797-3

Gozubuyuk, R., Kock, C.J. \& Unal, M. (2020). Who appropriates centrality rents? The role of institutions in regulating social networks in the global Islamic finance industry. Journal of International Business Studies, 51: 764-787. https://doi.org/10.1057/s41267-018-0202-4

Grossule, E. (2020) Risks and Benefits of the Increasing Role of ESMA: A Perspective from the OTC Derivatives Regulation in the Brexit Period. Social Indicators Research, 131(1): 169-187 https://doi.org/10.1007/s11205-016-1238-0

Hampl, M. \& Havranek, T. (2020). Central Bank Equity as an Instrument of Monetary Policy. Comparative Economic Studies. 62, 49-68. https://doi.org/10.1057/s41294-019-00092-1

Hathikal, S., Chung, S.H. \& Karczewski, M. (2020). Prediction of ocean import shipment lead time using machine learning methods. SN Applied Sciences. 2, 12-72. https://doi.org/10.1007/s42452-020-2951-5

Huang, J.-R. \& M.-L. Chang (2018). Fiscal transparency and foreign direct investment in China. The Singapore Economic Review, 63(4): 839-859.

Iurkov, V.\& Benito, G. R. (2018). Domestic alliance networks and regional strategies of MNEs: A structural embeddedness perspective. Journal of International Business $\quad$ Studies, 49(8): $\quad 1033-1059 . \quad \underline{\text { https://biopen.bi.no/bi- }}$ xmlui/bitstream/handle/11250/2574221/Domestic\%20alliance\%20networks\%202018.pdf?sequence $=4$ 


\section{ENTREPRENEURSHIP AND SUSTAINABILITY ISSUES}

ISSN 2345-0282 (online) http://jssidoi.org/jesi/ 2020 Volume 8 Number 2 (December) http://doi.org/10.9770/jesi.2020.8.2(2)

Judicial decisions. Cadbury Schweppes plc and Cadbury Schweppes Overseas Ltd. v. Commissioners of Inland Revenue (Case C-196/04), September 12, 2006. EUR-Lex. URL: https://eur-lex.europa.eu/legal-content/EN/ALL/?uri=CELEX\%3A62004CJ0196

Judicial decisions. Vodafone 2 v. RCC (2009) EWCA Civ 446 (CA). British and Irish Legal Information Institute. URL: http://www.bailii.org/ew/cases/EWCA/Civ/2009/446.html

Judicial decisions. C-298/05 Columbus Container Services BVBA \& Co v. Finanzamt Biele-feld-Innenstadt (2007) // ECR I-10451 (ECJ). URL: http://curia.europa.eu/juris/liste.jsf?language=en\&num=C-298/05

Kneller, R. \& Misch, F. (2014). The effects of public spending composition on firm productivity. Economic Inquiry, 52(4): 1525-1542. https://doi.org/10.1111/ecin.12092

Korableva, O. N., Kalimullina, O. V., \& Mityakova, V. N. (2018). Innovation activity data processing and aggregation based on ontological modelling. Paper presented at the 2018 4th International Conference on Information Management, ICIM 2018, 1-4. https://doi.org/10.1109/INFOMAN.2018.8392659

Kosov, M.E., Akhmadeev, R.G., Bykanova, O.A., Osipov, V.S., Ekimova, K.V. \& Frumina, S.V. (2016). Economic practicability substantiation of financial instrument choice. Journal of Applied Economic Sciences, 11(8): 1613-1623

Lampert, S., Bittermann, J-N. \& Harms, B. (2013). The CFC Regime in Germany. European Tax Studies, 20: 20-33.

Lehoux, L., Morozova, T.V., Safonova, E.G. \& Kalacheva, O.N. (2018). Adaptation of individual taxonomy in financial statements prepared in line with IFRS to XBRL format. Proceedings of the 32nd International Business Information Management Association Conference, IBIMA 2018 - Vision 2020: Sustainable Economic Development and Application of Innovation Management from Regional expansion to Global Growth, 2048-2055.

Linaa, J. (2020). Danish is as Danish does: Negotiating Ethnic Identities in Early Modern Elsinore, Denmark. International Journal of Historical Archaeology, 24: 284-317. https://doi.org/10.1007/s10761-019-00510-1

Lehoux, L., Morozova, T.V., Safonova, E.G., Balashova, A.D., \& Protasov, M.V. (2019). Practical Aspects in Calculating of Impairment of Financial Assets According to IFRS 9 "Financial Instruments". Proceedings of the 33rd International Business Information Management Association Conference, IBIMA 2019: Education Excellence and Innovation Management through Vision 2020, 6624-6632.

Majumder, A. \& Ray, R. (2020). National and subnational purchasing power parity: a review. Decision, 47: 103-124. https://doi.org/10.1007/s40622-020-00245-7

Monsenego J. (2012). Taxation of Foreign Business Income within the European Internal Market. Doctoral Series, 2(22): 160-170

Morozova, T.V., Akhmadeev, R.G., Bykanova, O.A. \& Philippova, N.V. (2019). Harmonizing the valuation standards of the EEU agricultiral companies. International Journal of Recent Technology and Engineering, 8(1), 2167-2177 https://www.ijrte.org/wpcontent/uploads/papers/v8i1/A1942058119.pdf

Nakamura, L. (2018). Creativity and economic growth: Theory, measures, and potentials for Morocco. Journal of Intellectual Capital, 19(3): 480-486.

Nigamaev, A. Z., Gapsalamov, A. R., Akhmetshin, E. M., Pavlyuk, A. V., Prodanova, N. A., \& Savchenkova, D. V. (2018). Transformation of the tax system during the middle ages: The case of Russia. European Research Studies Journal, 21(3), $242-253$.

Permikin, K.I. (2018). Features of the supranational regulation of the controlled foreign companies profit taxation in the European Union. Problems of economics and legal practice, 3(4): 264-285.

Perrone, A. (2020) EU Market Abuse Regulation: The Puzzle of Enforcement. European Business Organization Law Review, $21: 379-392$. https://doi.org/10.1007/s40804-019-00171-x

Petrova, G., Posadneva E. \& Morozova T. (2019). Leading the Labour Market by the Laws of Supply and Demand. In: Strielkowski W. (eds) Sustainable Leadership for Entrepreneurs and Academics. Springer Proceedings in Business and Economics. Springer, Cham, 263271 


\section{ENTREPRENEURSHIP AND SUSTAINABILITY ISSUES}

ISSN 2345-0282 (online) http://jssidoi.org/jesi/ 2020 Volume 8 Number 2 (December) http://doi.org/10.9770/jesi.2020.8.2(2)

Prodanova, N. A., Trofimova, L. B., Korshunova, L. N., Kamolov, S. G., Trapaidze, K. Z., \& Pavlyuk, A. V. (2019). The methods and evaluation of RIC integrated business indicators. International Journal of Innovative Technology and Exploring Engineering, 8(10), 18891894. https://doi.org/10.35940/ijitee.J9242.0881019

Puryaev, A. S., Puryaeva, Z. A., Kharisova, A. R., \& Puryaev, A. A. (2019). Investigation and explanation of mathematical tooling for accounting non-economic characteristics during the investment project effectiveness' assessing process. IOP Conference Series: Materials Science and Engineering, 570, 012074. https://doi.org/10.1088/1757-899X/570/1/012074

Rahman, P. A., Bobkova, E. Y. (2016). Reliability model of fault-tolerant data processing system with primary and backup nodes. IOP Conference Series: Materials Science and Engineering, 124(1), 148-156.

Sangiovanni, A. (2013). Solidarity in the European Union. Oxford Journal of Legal Studies, 33(2): 213-241.

Sazanov, O. V., \& Akhmetshin, E. M. (2016). Tax monitoring as an alternative to existing forms of tax control in Russia. Journal of Economics and Economic Education Research, 17(SpecialIssue), 15-20.

Seo, E., Kang, H. \& Song, J. (2020). Blending talents for innovation: Team composition for cross-border R\&D collaboration within multinational corporations. Journal of International Business Studies, 51: 851-885. https://doi.org/10.1057/s41267-020-00331-z

Thanou, S. (2020). Individual restrictive measures and actions for damages before the General Court of the European Union. ERA Forum.20: 599-614. https://doi.org/10.1007/s12027-019-00592-8

The Federal Tax Service. Data on forms of statistical tax reporting. https://www.nalog.ru/rn77/related_activities/statistics_and_analytics/forms/

Turishcheva T., Akhmadeev R., Bykanova O. \& Nastasyuk N. (2020). Methodological Support for Internal Control of Autonomous Institutions. International Journal of Applied Exercise Physiology. 9 (4): 53-61

Vertakova, Y., Mkrtchyan, V., \& Leontyev, E. (2019). Information provision of decision support systems in conditions of structural changes and digitalization of the economy. Journal of Applied Engineering Science, 17(1), 74-80.

Yemelyanov, V. A., Nedelkin, A. A., \& Olenev, L. A. (2019). An object-oriented design of expert system software for evaluating the maintenance of lined equipment. Paper presented at the 2019 International Multi-Conference on Industrial Engineering and Modern Technologies, FarEastCon 2019, https://doi.org/10.1109/FarEastCon.2019.8934414

\section{Liudmila Ivanovna KHORUZHY}

Doctor of Economics, Professor, the Head of the Department of Economics and management in agribusiness

Research interests - accounting expertise, financial control, audit, financial reporting in accordance with sustainable development, management accounting

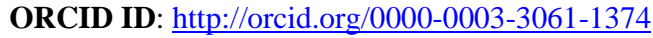

\section{Malvina Rasulovna KARABASHEVA}

Associate prof. of the accounting, analysis and audit department of the Financial University under the Government of the Russian Federation, Moscow, Russian Federation. Research interests - accounting expertise, state financial control, budgetary establishments, departmental interaction, efficiency of activity.

ORCID ID: https://orcid.org/0000-0003-3728-9867

\section{Hafis Ahmed oglu HAJIYEV}

PhD in Economics, Associate professor, Department of "Accounting and Audit", Faculty of "Finance and accounting", Azerbaijan State University of Economics (UNEC). Author specializes in the study of issues of improving accounting and the reporting in agricultural organizations. Currently engaged in teaching financial and management accounting at the Faculty "Finance and accounting" UNEC.

Research interests: Financial accounting, Financial statements, IFRS, Tax, Business.

ORCID ID: https://orcid.org/0000-0003-0805-8058 


\section{ENTREPRENEURSHIP AND SUSTAINABILITY ISSUES}

ISSN 2345-0282 (online) http://jssidoi.org/jesi/ 2020 Volume 8 Number 2 (December) http://doi.org/10.9770/jesi.2020.8.2(2)

Natalia Nikolaevna ZHADOBINA Ph.D. (Law.), Associate professor, Department of State and Municipal Law, Surgut State University. Expert in the field of state and municipal law. Research interests: Municipal law, Financial right, Tax law, Banking law, Municipal power: legal support.

ORCID ID: $\underline{\text { http://orcid.org/0000-0003-1720-6163 }}$

\section{Natalia Andreevna ALEKHINA}

Ph.D. of economics, Associate Professor at the Department of regulatory affairs in the sphere of drugs products and medical devices at Federal State Autonomous Educational Institution of Higher Education I.M. Sechenov First Moscow State Medical University of the Ministry of Health of the Russian Federation (Russian Federation, 119146, Moscow, Bolshaya Pirogovskaya str., 19/1, e-mails: romakinan@gmail.com , alekhina.na@1msmu.ru

ORCID ID: http://orcid.org/0000-0002-0356-7200

\section{Rustem Adamovich SHICHIYAKH}

Ph.D. (Econ.), Associate professor, Department of Management, Kuban State Agrarian University named after I.T. Trubilin. Expert in the field of state regulation of agriculture and sustainable tourism development. Research interests: state regulation of the economy, agriculture, sustainable development of tourism, rural areas, management, human capital, entrepreneurship

ORCID ID: http://orcid.org/0000-0002-5159-4350

Make your research more visible, join the Twitter account of ENTREPRENEURSHIP AND SUSTAINABILITY ISSUES: @Entrepr69728810

Copyright (C) 2020 by author(s) and VsI Entrepreneurship and Sustainability Center

This work is licensed under the Creative Commons Attribution International License (CC BY).

http://creativecommons.org/licenses/by/4.0/

cC) (i) Open Access 